\title{
Teaching Literature in the Age of E-Literacy
}

\author{
Anne Mabry
}

New Jersey City University

\begin{abstract}
In this piece of writing the writer deals with the issue of teaching literature and with the use of technology for the purpose of human resource development in the age of internet.
\end{abstract}

Students in urban high schools across the United States have been struggling to accomplish one milestone that most other students in suburban U.S. high schools take as a rite of passage-graduating from high school. In the recent report titled "Closing the Graduation Gap," commissioned by the American's Promise Alliance, a non-profit group that works to reduce America's high school dropout rates, the average high school graduation rate in the U.S.'s 50 largest cities was 53 percent, compared with 71 percent in the suburbs. And the magnitude of the problem doesn't stop there. As reported by Sara Rimer of the New York Times just a few months ago, of the 68 percent of high school students nationwide who go to college each year, about one-third begin their freshmen year with skills deficient in writing, reading, and basic computational skills.

Rupkatha Journal on Interdisciplinary Studies in Humanities

Summer Issue, Volume I, Number 1, 2009

URL of the journal: www.rupkatha.com/issue0109.php

URL of the article: www.rupkatha.com/0109teachingliteratureintheageofeliteracy.pdf

(C) www.rupkatha.com 
At New Jersey City University (NJCU), in Jersey City, New Jersey, incoming freshmen (a little over 500 full-time admitted in Fall 2008) who need remedial courses is a phenomenon that faculty are all too familiar with. Many are children of immigrants. Most have parents who never graduated from college. All aspire to be middle class. They know that a high school diploma is no longer the ticket to social mobility in the U.S.; the manufacturing economy that once easily absorbed such students and allowed them to support a family has all but disappeared in the past decades.

The question is: What does this have to do with teaching literature and human nature in the freshmen writing courses? The answer is: Everything.

Let's start with reading. The typical freshmen at NJCU read only because they are required to; the number of hours per week spent on academic reading is far less than the number of hours per week spent on watching television, text messaging, emailing, or instant messaging (IM). Students in my second semester freshmen writing class, English Composition II, confess that they don't read the newspaper daily, much less read books for leisure. They plainly live in the Age of Instant Electronic Feedback. In this age, the emphasis is on get-yourmessage-across-as quickly-as-possible-because-l'm-driving-eating-walking.

A typical text/email/IM message is as follows: "This is Lisa M. from your english class that will be meeting today at 10 , yesterday i got really bad sunburn on my leg, $\mathrm{n}$ minor sunburn on parts of my arm. The worst place that i go sunburn is near my armpit and everytime i put my arms down it burns, i told professor Thurston that i will not be attending his class today, I was wondering if it would be okay if $\mathrm{i}$ missed our english class too but $\mathrm{i}$ remember you saying to come to class." Lisa (not her real name) is, in fact, one of the better writers in the class.

Of course, in the Age of Instant Electronic Feedback, it is not fair to judge a student's writing ability or potential based on what I will call "e-prose" since that prose adopts well-known rules: 1 ) lowercase letters in place of uppercase letters; 2) "u" for "you"; and 3) commas or maybe not at all for periods. College writing teachers, please add your own rules.

My point is this: good writing (writing a good essay) takes time. It takes time because one has taken the time to read. Reading well is an acquired habit. 
Telling this to my students often results in suspicious smiles. "Oh really, Professor," they think. "Time is the whole issue."

"Take me," for example, I said one day early in the semester. "I have two children and we don't have a television." After explaining, No, I'm not joking, and, Yes, my kids really are perfectly normal, I decide it's time to delve into my ammunition by the next class. "Look at this article," I explain. Ready at the draw is a neat pile of photocopied handouts-selected chapters from Neil Postman's Amusing Ourselves to Death: Public Discourse in the Age of Show Business," a top ten on the non-existent list of must-read books required of all NJCU freshmen. "Read for next class."

Chapter two of Postman's book opens with an ambitious purpose: "It is my intention in this book to show that a great media-metaphor shift has taken place in America, with the result that the content of much of our public discourse has become dangerous nonsense" (16). But I don't start the class discussion with that quote. I start with chapter four of the Lincoln-Douglas debates that took place on August 21, 1858, in Illinios. We look at the reading and examine two important questions: Question one is, What kind of audience was it that would patiently sit through four-plus hours of talk in an un-air conditioned auditorium, and plainly enjoy it? Question two is, How has our public discourse changed since then as a result of mass media? The answer to question one is, in short, that these were people who were quite accustomed to extended oratorical performances. Postman answers it best: "The Gettysburg Address would probably have been largely incomprehensible to a 1985 audience." The answer to the second question is more complex. Perhaps another quote from Postman will help: "It is quite likely that most of the first fifteen presidents of the United States would not have been recognized had they passed the average citizen in the street....To think about those men was to think about what they had (written my emphasis)" (61). We then move on to discuss the difference between thinking in a word-centered culture versus thinking in an image-centered culture. What implications does this have on their writing in college? Topic for Essay \#1.

Back to pedagogy. Or rather, on to pedagogy. How does one teach writing effectively (albeit not a subjective term) when students are not readers? 
There is no ready palliative for this bitter pill. So I begin my quest: Teaching Human Nature Through Literature That is Meaningful to NJCU Freshmen.

We begin with the following question: "Can technology expand the possibilities for creativity, free humans from drudgery and deadening routines, and bring them into closer communication with one another and with nature? Or might technology instead blunt the imagination, increase dependency on technology, and alienate humans from each other and nature?" I ask students to be able to answer this question after reading E.M. Forster's prescient novella, The Machine Stops, and then selections from Kurt Vonnegut's Player Piano and Henry David Thoreau's Walden. Topic for Essay \#2.

We find that technology is, in fact, deceptively attractive; it does expand the possibilities for creativity because we are freed from drudgery. The problem is that technology imposes its own deadening routines and alienates humans from each other-despite instant communication-and alienates humans from nature. Thoreau's adage, "Simplicity, simplicity, simplicity!" is almost impossible in the Age of Planned Obsolescence.

We move on. Perhaps we as a society should review and rethink what Plato and More and the Daoists had to say about pastoralism-maybe that is a solution for man's happiness. Alas, Plato does not allow a place for the arts and poetry and music in his rigorous system of education; More is too static; the Daoists may have it right, after all. But as one of my students pointed out after reading the selection of Chinese poetry, "We are too busy working 20 hours, going to school, finding a babysitter, and worrying about paying our bills to 'blow whichever way the wind blows."'

We move on again: What does the dystopian literature have to say about human nature? We explore the following question: If present trends continue, will man experience complete alienation from his culture/environment, and see the rise of tyranny? We read Aldous Huxley's Brave New World. Students agree with Huxley's premise that we are on a pleasure-seeking, consumer-oriented path. They see that George Orwell's premonitions in Nineteen Eighty-four have a much darker color. We look at the features of a totalitarian society and see if there are hints of that in our own society. There are. Topic for Essay \#3. 
Throughout this quest, the students are given the time and space to read and question. They must make connections: What is similar between what Plato is saying and what Thoreau is saying? In what way is the work by Forster and Vonnegut a warning to contemporary society? This buzzword, "critical thinking," I tell my students, is really just all about making connections between things that on the surface only look dissimilar. And then making that connection to their own lives.

And the quest goes on. It is no longer just mine. It is now the students' quest. And like Gilgamesh, as they further develop their critical thinking at the university, they will become transformed as a result.

\section{Works Cited}

- America's Promise Alliance. "Cities in Crisis in 2009: Closing the Graduation Gap." Editorial Projects in Education Research Center: 2009.

- Postman, Neil. Amusing Ourselves to Death: Public Discourse in the Age of Show Business. New York: Penguin Books, 1985.

- Rimer, Sarah. "Urban Schools Aiming Higher Than Diploma." New York Times, 18 Jan. 2008. Education.

Writer: Anne Mabry, Associate Professor, ESL, New Jersey City University, USA. E-mail: amabry@njcu.edu 